\section{College Reports}

Following the endorsement by Council of the revised procedures for the dissemination of Council Reports, the Executive and Finance Committee at its meeting on 13 November 1992 agreed that a list of titles of recently published Council Reports should appear in the Psychiatric Bulletin, biannually, in order to bring these to the attention of the membership. (See Psychiatric Bulletin, February 1992, 17, 124).

\section{College Council Reports}

Secure Facilities for Psychiatric Patients. A Comprehensive Policy

$£ 2.00$ Council Report CR1 1980

Psychiatric Rehabilitation in the 1980s

$£ 2.00$ Council Report CR2 1980

Mental Handicap Services. The Future

$£ 2.00$ Council Report CR4 1983

HIV Disease and Psychiatric Practice

$£ 2.50$ Council Report CR5 1989

Consent of Non-Volitional Patients and 'De Facto'

Detention of Informal Patients

$£ 2.00$ Council Report CR6 1989

Position Statement on Confidentiality

$£ 2.00$ Council Report CR7 1989

Guidelines to Good Practice in the Use of Behavioural

Treatments

$£ 2.00$ Council Report CR9 1989

Psychiatric Practice and Training in British

Multi-ethnic Sociey

f4.00 Council Report CR10 1990

Report on the College's Preliminary Visit to South Africa

$£ 2.50$ Council Report CR11 1990

Good Medical Practice in the Aftercare of Potentially

Violent or Vulnerable Patients Discharged from

Inpatient Psychiatric Treatment

£2.00 Council Report CR12 1991

Homelessness and Mental Illness

£2.00 Council Report CR13 1991

Eating Disorders

$£ 2.00$ Council Report CR14 1992
Ethical Issues in Psychiatric Practice in Prisons $£ 2.00$ Council Reports CR15 1992

Psychiatric Services for Children and Adolescents with Mental Handicap

$£ 2.00$ Council Report CR17 1992

\section{College Occasional Papers}

List of Books Suitable for a Psychiatric Library 1983-1987

£2.00 Occasional Paper OP1 1988

List of Books Suitable for a Psychiatric Library 1988 $£ 2.00$ Occasional Paper OP4 1989

Index to Statements, Guidelines and Policy Documents of the College 1971-89

$£ 2.50$ Occasional Paper OP6 1989, with annual supplements

Child and Adolescent Psychiatry: Into the 1990s

£5.00 Occasional Paper OP8 1990

List of Books Suitable for a Psychiatric Library 1989-90

£2.00 Occasional Paper OP10 1990

Reading List for Trainees. Basic Sciences $£ 2.00$ Occasional Paper OP11 1991

Proceedings of the Children Act Course 1989 $£ 5.00$ Occasional Paper OP12 1991

List of Books Suitable for a Psychiatric Library (Supplement 3) 1991

£2.00 Occasional Paper OP13 1991

Psychiatric Associations of the World £3.00 Occasional Paper P14 1992

Reading List for Trainees. General Psychiatry $£ 2.00$ Occasional Paper OP15 1992

Psychiatric Instruments and Rating Scales: A Select Bibliography

£7.50 Occasional Paper OP16 1992

Please send orders, with cheques made payable to the Royal College of Psychiatrists, to the Publications Department at the College. A full list of books published by the College is available on request. 